\title{
Cryopreservation and Quality Assessment of Buffalo Bull (Bubalus bubalis) Semen Using New Moringa Extender and Antioxidant Co-q10 Doidar, Y. A. ${ }^{1}$; H. A. El-Nagar ${ }^{2}$; A. Elrefy ${ }^{1}$ and A. M. Mousbah ${ }^{1}$ ${ }^{1}$ Biotechnology Department, Faculty of Agriculture, Al-Azhar University, Nasr City, Egypt, 11884.
}

${ }^{2}$ Animal Production Research Institute, Agricultural Research Center, Dokki, Giza, Egypt.

\section{ABSTRACT}

Low fertility in buffaloes with frozen-thawed semen is attributed to sperm damage that is related to formation of ice crystals during freeze/thaw process. This study was conducted to evaluate the freezability of buffalo bull semen extended with four types of extenders, including citrate egg-yolk (CEY, control), CEY with ethanolic Moringa Olifera Leaf Extract (eMOLE) as replacement of antibiotics (CEYm), eMOLE and eMOLE with conventional antibiotic (eMOLEa) with or without Coenzyme Q10 as antioxidant. Semen was subjected to calculate progressive motility, livability, abnormality, acrosome status and integrity of sperm membrane in semen after extending, equilibrating and thawing processes. Four sexually mature buffalo bulls (4-5 y and 400-450 kg LBW) were used for semen collection, and semen was collected twice weekly for 4 successive weeks. Semen ejaculates of $\geq 70 \%$ as mass motility percentage were pooled and extended at $37^{\circ} \mathrm{C}$ by the four types of extenders without or with $\left.30 \mu \mathrm{M} \mathrm{Co}-\mathrm{Q} 10\right)$. Results cleared that progressive motility, livability, abnormality, acrosomal damage and plasma membrane integrity percentages improved $(\mathrm{P}<0.05)$ in buffalo semen after dilution, equilibration and thawing, while activity of AST, ALT and LDH in seminal plasma of post-thawed semen reduced $(\mathrm{P}<0.05)$ by extension of semen with eMOLE as a new extender. All sperm parameters and enzyme activity were maintained by replacing antibiotics in CEY extender with $4 \mathrm{ml}$ eMOLE. All sperm parameters were improved $(\mathrm{P}<0.05)$ and enzyme activity was maintained by adding $30 \mu \mathrm{M}$ of coQ10 as compared to free extenders. Fertility rate of buffalo cows inseminated with semen cryopreserved in extender (eMOLE+coQ10) was the highest (91.6\%), followed by eMOLE without coQ10 (83.3\%) and the lowest for control CEY (66.6\%). In conclusion, eMOLE as a new extender, is promising for the extension and preservation of buffalo semen. Also, adding $4 \mathrm{ml}$ of eMOLE could be a good substitute for the antibiotic component of CEY as a conventional semen extender. Moreover, supplementing semen extenders with antioxidant addition $(30 \mu \mathrm{M} \mathrm{CoQ} 10)$ is important to improve function of spermatozoa and sperm fertility of cryopreserved semen of buffaloes.

Keywords: buffalo semen, extender, Moringa, antimicrobial, coenzyme Q10, cryopreservation.

\section{INTRODUCTION}

Semen cryopreservation methods for buffalo have obtained more importance as application of artificial insemination (AI) with frozen thawed spermatozoa and expanded universally. However, the data about standardized protocol for buffalo cryopreservation production is limited (Akhter et al., 2013). During cryopreservation procedures, sperm cells exposed to oxygen and this could generate reactive oxygen species (ROS), leading to oxidative damage to spermatozoa (Chatterjee et al., 2001). Oxidative stress happened because of the imbalance between the productions of ROS and the defensive activity of antioxidant system responsible for their removal (Walczak et al, 2012). These hazards can be minimized by optimizing appropriate diluting media (extenders) in which spermatozoa are frozen and fortification by supplementation with antioxidant (Sansone et al., 2000; Kadirve et al, 2014).

Bacteria is highly influencing the results of viability and fertility of cryopreserved spermatozoa. Bacteria may affect spermatozoa directly, by adhering to spermatozoa, impairing their motility and inducing acrosome reaction, or indirectly by producing toxins. Subsequently, utilizing different antibiotics in the extender is essential to control these bacteria for obtaining the best results of AI (Thibier and Guerin, 2000; Andrabi, 2009; Mughal et al., 2017).

Moringa oleifera (MO) Lam, belongs to the monogeneric family Moringaceae. Extract of MO (leaves, seeds and roots) have been broadly examined for numerous potential uses as antioxidant, antibacterial, anti-fertility, anti-inflammatory, antifungal etc. (Sadek et al., 2013; Sokunbi et al., 2015). Moringa leaves considered a rich source of antioxidants, in addition to preventing oxidative stress. Moringa as aqueous and ethanolic leaf extracts were shown to contain compounds with wide-spectrum antibacterial activity, competence for repressing the growth of gram-positive and negative bacteria (Peixoto et al, 2011). Contents of phenolic and flavonoids in Moringa leaves were almost two or three times that of vegetables (Pakade et al., 2013). According to several authors, phenolic and flavonoids are straight forwardly connected to antioxidant potential by scavenging free radicals (Siddhuraju and Becker, 2003; Lukacinova et al., 2008). Moringa treatment enhanced the reproductive potentials, because of low concentration of free radical scavenging enzymes in sperm cytoplasm (D'cruz and Mathur, 2005). Recently, the positive effect of using MOLE as an extender of Friesian bull semen or as an antioxidant additives was reported by El-Nagar (2017).

Coenzyme Q10 (co-Q10) is non-enzymatic antioxidant, lipid-soluble molecule, found in mitochondrial membrane of every mammal cells. This molecule possesses an important role in the synthesis of adenosine triphosphate (ATP) (Pindaru et al., 2013). Such molecule is also involved in gene expression (Tomono et al., 1986). It is also found endogenously in the mitochondria in the mid-piece region of spermatozoa and involved in energy production (Kapoor and Kapoor, 2013). Antioxidants such as coQ10 can neutralize free radicals and may reduce or even help prevent some of the damage they cause like cell membrane damage, tamper with DNA, and cell death. CoQ10 inhibits lipid peroxidation by preventing the production of lipid peroxyl radicals. By preventing propagation of lipid peroxidation, coQ10 protects not only lipids, but also proteins from oxidation (Saeed et al., 2016). The successful use of coQ10 as an antioxidant in in vitro maturation medium was proved in rabbit oocytes by Abdel-Khalek et al. (2016).

Therefore, the current study was undertaken to evaluate the freezability and fertility of buffalo bull semen extended with four types of extenders, including citrate egg-yolk (CEY, control), CEY with ethanolic Moringa Olifera Leaf Extract (eMOLE) as replacement of 
antibiotics (CEYm), EMOLE and eMOLE with conventional antibiotic (eMOLEa) with or without Coenzyme Q10 as antioxidant.

\section{MATERIALS AND METHODS}

The experimental work of this study was carried out at Research Station of Animal Production, ElGemmezah, Gharbiya Governorate, belonging to Animal Production Research Institute, Egypt, and Biotechnology Department, Faculty of Agriculture, Al-Azhar University. Animals and management:

Four healthy mature buffalo bulls aging 4-5 years and 400-450 kg live body weight were used as semen donors and individually housed under semi-open sheds. The external genetalia were typically intact and normal. Feeding system of all experimental bulls included daily diet involved $8 \mathrm{~kg}$ concentrate mixture, $4 \mathrm{~kg}$ clover hay and $4 \mathrm{~kg}$ rice straw. At all day times, fresh water and mineral blocks were available during semen collection period.

Semen collection:

Semen was collected (twice/week) from the bulls for 4 weeks using an artificial vagina (IVM, France) method, before feeding at 8.00 a.m. Two successive ejaculates were obtained from each bull at each day of semen collection. The collected ejaculates (32 ejaculates with mass motility of $\geq 70 \%$ ) were taken immediately in water bath $\left(37^{\circ} \mathrm{C}\right)$ to the laboratory. On each collection day, semen was pooled and divided into 8 replicates for different semen treatments (4 types of extenders $\mathrm{x}$ with or without coQ10).

\section{Types of extenders and treatment:}

Semen was extended using four different extenders as shown in table (1), including: Citrate Egg Yolk (CEY) and served as control, CEY with ethanolic Moringa Olifera Leaf Extract (eMOLE) instead of antibiotics (CEYm), eMOLE supplemented with anti-biotics (eMOLEa) or eMOLE without antibiotics as a new extenders. The eMOLE (Egyptian Scientific Society of Moringa, National Research Center, Egypt) was prepared according to the method of Ugwu Okechukwu et al. (2013).

The extenders were kept at $37^{\circ} \mathrm{C}$ until the dilution. Semen extended with different types of extenders were used without or with $30 \mu \mathrm{M}$ Co-q10 (Sigma-Aldrich, 1g). Each extender was prepared and warmed in water bath $\left(37^{\circ} \mathrm{C}\right)$, and semen was extended for each extender type at a rate of $1: 20$.

Table 1. The composition of the four extenders (CEYa, CEYm, MOLEa and eMOLEE).

\begin{tabular}{lcccccc}
\hline Extender & Sodium Citrate (g) & eMOLE $(\mathbf{m l})$ & Fructose $(\mathrm{g})$ & streptomycin sulphate (mg) & Penciline (IU) & Saline Solution (ml) \\
\hline $\mathrm{CEY}^{(1)}$ & 2.9 & - & 0.5 & 1.0 & 100.000 & - \\
$\mathrm{CEYm}^{(1)}$ & 2.9 & 4 & 0.5 & - & - & - \\
$\mathrm{eMOLEa}^{(2)}$ & - & 10 & 0.7 & 1.0 & 100.000 & 100 \\
$\mathrm{eMOLE}^{(2)}$ & - & 14 & 0.7 & - & - & 100 \\
\hline
\end{tabular}

(1) CEY: Mixture of sodium citrate, fructose, Streptomycin sulphate and Penciline were added to 100 ml distilled water.

(2) MOLE: Mixture of eMOLE, fructose, Streptomycin sulphate and Penciline were mixed in $100 \mathrm{ml}$ saline solution.

Egg yolk $(16 \mathrm{ml})$ and glycerol $(8 \mathrm{ml})$ were added to $76 \mathrm{ml}$ of the mixture in CEY and eMOLE.

\section{Semen cryopreservation:}

The diluted semen was placed in a water bath $(37 \circ \mathrm{C})$, then gradually cooled in a refrigerator $\left(5^{\circ} \mathrm{C}\right)$ for $4 \mathrm{~h}$ as a period of equilibration. Extended semen was kept in iced water bath before filling in straws to keep its temperature $\left(5^{\circ} \mathrm{C}\right)$, then straws were filled with semen in $0.25 \mathrm{ml}$ French straws. The equilibrated semen was transferred into processing container and located horizontally in static nitrogen vapor $4 \mathrm{~cm}$ on the surface of liquid nitrogen $(\mathrm{LN})$ at $-196^{\circ} \mathrm{C}$ for $10 \mathrm{~min}$, then the straws were placed vertically in a metal canister and immersed completely in LN container for 5 weeks.

Frozen straws were withdrawn from the liquid nitrogen container and semen were thawed at $37^{\circ} \mathrm{C}$ for 30 seconds, then the semen samples were evaluated.

\section{Semen evaluation:}

Semen after dilution, equilibration and thawing was evaluated for progressive sperm motility percentage under a phase contrast microscope (Penta View LCD Digital Microscope) with closed circuit television (Ewuola and Egbunike, 2010). The motility was examined after dilution, equilibration and thawing. Sperm livability percentage was evaluated using Eosin and Nigrosin Stain (Mughal et al, 2013) by counting 100 spermatozoa per slide. Abnormal sperm percentage was assayed by staining smears with Eosin-Nigrosin according to Campell et al. (1956) by light microscope. All sperm cells with coiled or double tail, damaged mid-piece and damaged or detached head were considered abnormal (Ewuola and Egbunike, 2010).
For acrosomal Integrity, the method of Jankovicova et al. (2006) was used with slight modification. 0.2\% trypan blue solution was prepared. An equal quantity of semen and trypan blue was placed and smeared on a prewarmed slide and fixed for 2 minutes with fixative solution containing $86 \mathrm{~mL}$ of $1 \mathrm{~N} \mathrm{HCL}$ and $14 \mathrm{ml}$ of $37 \%$ formaldehyde. The spermatozoa (100 in number) were evaluated for their normal apical ridge by using phasecontrast microscope. Intact acrosome were light colored while damaged acrosome were violet stained.

Plasma membrane integrity was assessed using hypo-osmotic swelling (HOS) assay (Khan and Ijaz, 2008). HOS solution was prepared, $50 \mu 1$ of semen mixed with $500 \mu \mathrm{l}$ of pre-warmed $37^{\circ} \mathrm{C}$ HOS solution and incubated $37^{\circ} \mathrm{C}$ for 45 minutes. One hundred spermatozoa were counted and the number of spermatozoa showing characteristic swelling of tail, an indicative of intact plasma membrane, was recorded. The PMI was examined after dilution, equilibration and thawing.

\section{Enzyme activity:}

Enzyme activity of aspartate amino-transaminases (AST), alanine amino-transaminases (ALT) and lactic dehydrogenase (LDH) was determined (Young, 1990) in seminal plasma of semen in each extender type after thawing by commercial Kits (Salucea Netherlands) and spectrophotometer (JENWAY-6405 UV/Vis).

\section{Fertility trail:}

Estrous synchronized 36 sexually mature buffalo cows were taken from Al-Gemmizah Research Station. 
These cows were randomly divided into 3 similar groups, 12 cows in each. Buffalo cows were synchronized by i.m. injection of $3 \mathrm{ml}$ Estrumate (PGF2 $\alpha$-Essex Animal Health Friesoythe, Germany). Cows in heat after 48-72 h of synchronization were artificially inseminated with semen with each extender with or without antioxidant. Semen was thawed at a rate of $37^{\circ} \mathrm{C}$ for $30 \mathrm{~s}$ using filled plastic AI gun close to the cervix by the same inseminator. Pregnancy was diagnosed on day 50 post-AI by rectal palpation.

Statistical analysis:

The collected data were statistically analyzed by ANOVA in factorial design (4 types of extender $\times 2$ antioxidants) using SPSS (2013) program. The significant differences at least at $\mathrm{P}<0.05$ ) were tested using Duncan Multiple Rang test (Duncan, 1955). Arcsine transformation before performing the analysis of variance was done for the percentage values, then means as percentages were recalculated from the transformed values.

\section{RESULTS}

Characteristics of spermatozoa in buffalo semen after dilution:

Data in Table (2) cleared that all characteristics of spermatozoa were significantly $(\mathrm{P}<0.05)$ better in semen diluted with eMOLE extender, poorer in semen diluted with eMOLEa, but did not differ in semen diluted with CEYm as compared to that diluted with CEY.

As affected by coQ10 addition, all sperm parameters were better in semen diluted with than without coQ10 addition. However, the interaction effect between type of extender and coQ10 on all sperm parameters was not significant (Table 2), reflecting the best characteristics in buffalo semen diluted with eMOLE with coQ10.

It is of interest to observe that all characteristics were significantly $(\mathrm{P}<0.05)$ lower in semen diluted with eMOLEa as compared to the same extender without antibiotics even the control extender (Table 2).

Table 2. Characteristics of spermatozoa in post-diluted buffalo semen as affected by type of extender, coQ10 addition and their interaction.

\begin{tabular}{|c|c|c|c|c|c|}
\hline \multirow{2}{*}{ Item } & \multicolumn{5}{|c|}{ Characteristics (\%) of spermatozoa } \\
\hline & Motile & Live & Abnormal & Acrosome damage & HOS-t \\
\hline \multicolumn{6}{|l|}{ Extender type (ET): } \\
\hline CEY (control) & $65.63^{\mathrm{D}}$ & $64.63^{\mathrm{D}}$ & $17.94^{\mathrm{v}}$ & $17.50^{\mathrm{D}}$ & $63.13^{\mathrm{D}}$ \\
\hline CEYm & $67.19^{\mathrm{b}}$ & $65.44^{\mathrm{b}}$ & $16.94^{\mathrm{b}}$ & $16.75^{\mathrm{b}}$ & $64.13^{\mathrm{b}}$ \\
\hline eMOLEa & $60.00^{\mathrm{c}}$ & $59.81^{\mathrm{c}}$ & $21.44^{\mathrm{a}}$ & $20.19^{\mathrm{a}}$ & $57.56^{\mathrm{c}}$ \\
\hline eMOLE & $72.19^{\mathrm{a}}$ & $72.00^{\mathrm{a}}$ & $14.25^{\mathrm{c}}$ & $13.69^{c}$ & $70.31^{\mathrm{a}}$ \\
\hline SEM & 1.09 & 1.23 & 0.57 & 0.57 & 0.96 \\
\hline \multicolumn{6}{|l|}{ Antioxidant (A): } \\
\hline Without coQ10 & 63.91 & 62.75 & 19.09 & 18.50 & 61.31 \\
\hline $\begin{array}{l}\text { With coQ10 (30 } \\
\mu \mathrm{M})\end{array}$ & 68.59 & 68.19 & 16.19 & 15.56 & 66.25 \\
\hline SEM & 0.77 & 0.87 & 0.39 & 0.40 & 0.68 \\
\hline P-value & $0.000 * * *$ & $0.000 * * *$ & $0.000 * * *$ & $0.000 * * *$ & $0.000 * * *$ \\
\hline \multicolumn{6}{|l|}{ Interaction (ET x A): } \\
\hline $\mathrm{P}$-value & ns & ns & ns & ns & ns \\
\hline
\end{tabular}

Means in the same column for each factor with different superscripts differ significantly $(\mathrm{P}<0.05)$.

ns: Not significant. ${ }^{* * *}$ Significant at $\mathbf{P}<0.001$.

Characteristics of spermatozoa in buffalo semen after equilibration:

Data in Table (3) revealed the same trend of differences in characteristics of spermatozoa among different extender types or in extender without or with
coQ10 in semen after equilibration as found in semen after dilution. However, percentages of motility, livability and HOS-t were lower, while percentages of abnormality and acrosome damage were higher in semen after equilibration than in that after dilution.

Table 3. Characteristics of spermatozoa in post-equilibrated buffalo semen as affected by type of extender, coQ10 addition and their interaction.

\begin{tabular}{|c|c|c|c|c|c|}
\hline \multirow{2}{*}{ Item } & \multicolumn{5}{|c|}{ Characteristics (\%) of spermatozoa } \\
\hline & Motile & Live & Abnormal & Acrosome damage & HOS-t \\
\hline Extender type (ET): & & & & & \\
\hline CEY (control) & $60.94^{\mathrm{b}}$ & $61.44^{\mathrm{b}}$ & $20.81^{\mathrm{b}}$ & $19.63^{\mathrm{b}}$ & $59.25^{\mathrm{b}}$ \\
\hline CEYm & $61.44^{\mathrm{b}}$ & $61.25^{\mathrm{b}}$ & $20.06^{\mathrm{b}}$ & $19.50^{\mathrm{b}}$ & $59.75^{\mathrm{b}}$ \\
\hline eMOLEa & $48.75^{\mathrm{c}}$ & $50.06^{\mathrm{c}}$ & $25.94^{\mathrm{a}}$ & $24.94^{\mathrm{a}}$ & $47.63^{\mathrm{c}}$ \\
\hline eMOLE & $69.38^{\mathrm{a}}$ & $69.06^{\mathrm{a}}$ & $15.69^{\mathrm{c}}$ & $15.44^{\mathrm{c}}$ & $66.94^{\mathrm{a}}$ \\
\hline SEM & 1.14 & 1.12 & 0.64 & 0.57 & 1.05 \\
\hline Antioxidant (A): & & & & & \\
\hline Without coQ10 & 58.75 & 59.28 & 21.72 & 20.91 & 57.25 \\
\hline With coQ10 $(30 \mu \mathrm{M})$ & 61.50 & 61.63 & 19.53 & 18.84 & 59.53 \\
\hline SEM & 0.81 & 0.79 & 0.45 & 0.40 & 0.74 \\
\hline P-value & $0.019^{*}$ & $0.041 *$ & $0.001 * * *$ & $0.001 * * *$ & $0.034 *$ \\
\hline Interaction (ET x A): & & & & & \\
\hline P-value & ns & ns & ns & ns & ns \\
\hline
\end{tabular}

NS: Not significant. * Significant at $\mathrm{P}<0.05$. *** Significant at $\mathrm{P}<0.001$.

Characteristics of spermatozoa in buffalo semen after thawing:

Data in Table (4) showed similar differences in all characteristics among different extender types or in extender without or with coQ10 in semen after thawing as found in those after dilution and equilibration. There was marked decrease in percentages of motility, livability and HOS-t and marked increase in percentages of abnormality and acrosome damage in semen after thawing as compared to in semen after dilution and equilibration. 
Table 4. Characteristics of spermatozoa in post-thawed buffalo semen as affected by type of extender, coQ10 addition and their interaction.

\begin{tabular}{|c|c|c|c|c|c|}
\hline \multirow{2}{*}{ Item } & \multicolumn{5}{|c|}{ Characteristics (\%) of spermatozoa } \\
\hline & Motile & Live & Abnormal & Acrosome damage & HOS-t \\
\hline $\begin{array}{l}\text { Extender type (ET): } \\
\text { CEY (control) }\end{array}$ & $44.67^{\mathrm{b}}$ & $47.31^{\mathrm{b}}$ & $28.56^{\mathrm{b}}$ & $26.88^{\mathrm{b}}$ & $44.94^{\mathrm{b}}$ \\
\hline CEYm & $46.25^{\mathrm{b}}$ & $48.50^{\mathrm{b}}$ & $28.06^{\mathrm{b}}$ & $26.56^{\mathrm{b}}$ & $45.56^{\mathrm{b}}$ \\
\hline eMOLEa & $39.38^{\mathrm{c}}$ & $41.75^{\mathrm{c}}$ & $31.62^{\mathrm{a}}$ & $29.44^{\mathrm{a}}$ & $38.38^{\mathrm{c}}$ \\
\hline eMOLE & $56.25^{\mathrm{a}}$ & $57.38^{\mathrm{a}}$ & $21.69^{\mathrm{c}}$ & $20.69^{c}$ & $58.38^{\mathrm{a}}$ \\
\hline SEM & 1.13 & 1.28 & 0.58 & 0.62 & 0.88 \\
\hline Antioxidant (A): & & & & & \\
\hline $\begin{array}{l}\text { Without coQ10 } \\
\text { With coQ10 (30 } \\
\mu \mathrm{M})\end{array}$ & $\begin{array}{l}44.38 \\
48.91\end{array}$ & $\begin{array}{l}46.37 \\
51.09\end{array}$ & $\begin{array}{l}28.81 \\
26.17\end{array}$ & $\begin{array}{l}26.84 \\
24.94\end{array}$ & $\begin{array}{l}44.38 \\
49.25\end{array}$ \\
\hline SEM & 0.80 & 0.90 & 0.41 & 0.44 & 0.62 \\
\hline $\mathrm{p}$-value & $0.000 * * *$ & $0.001 * * *$ & $0.000 * * *$ & $0.003 * *$ & $0.000 * * *$ \\
\hline $\begin{array}{l}\text { Interaction }(\text { ET x A): } \\
\text { P-value }\end{array}$ & ns & $\mathrm{ns}$ & ns & ns & ns \\
\hline
\end{tabular}

Means in the same column for each factor with different superscripts differ significantly $(\mathrm{P}<0.05)$.

NS: Not significant. ** Significant at $\mathrm{P}<0.01$. *** Significant at $\mathrm{P}<0.001$.

Enzyme activity in seminal plasma of semen after thawing:

Data in Table (5) showed the lowest activity of AST, ALT and LDH in seminal plasma of thawed semen diluted with eMOLE as compared to other types of extenders, but the differences were significant $(\mathrm{P}<0.05)$ only for ALT and LDH activities. However, the corresponding activities were the significantly $(\mathrm{P}<0.05)$ the highest in seminal plasma of thawed semen diluted with eMOLEa, reflecting the best sperm traits with eMOLE and opposite trends in eMOLEa.

On the other hand effect of coQ10 addition resulted in significant $(\mathrm{P}<0.05 ; \mathrm{P}<0.01)$ reduction of all enzyme activities in seminal plasma as compared to those without coQ10. The interaction effect between type of extender and coQ10 on all enzyme activities was not significant (Table 5), reflecting the lowest enzyme activity in buffalo semen diluted with eMOLE with coQ10.

Table 5. Enzyme activity of AST, ALT and LDH in seminal plasma of post-thawed buffalo semen as affected by type of extender, coQ10 addition and their interaction.

\begin{tabular}{lccc}
\hline \multirow{2}{*}{ Item } & \multicolumn{3}{c}{ Enzymatic Activity } \\
\cline { 2 - 4 } & AST & ALT & LDH \\
\hline Extender type (ET): & & & \\
CEY (control) & $29.40^{\mathrm{b}}$ & $27.40^{\mathrm{b}}$ & $267.20^{\mathrm{b}}$ \\
CEYm & $28.00^{\mathrm{b}}$ & $23.90^{\mathrm{bc}}$ & $240.40^{\mathrm{c}}$ \\
eMOLEa & $43.30^{\mathrm{a}}$ & $35.10^{\mathrm{a}}$ & $288.60^{\mathrm{a}}$ \\
eMOLE & $26.20^{\mathrm{b}}$ & $21.20^{\mathrm{c}}$ & $224.20^{\mathrm{c}}$ \\
ESM & 1.46 & 1.28 & 6.24 \\
\hline Antioxidant (A): & & & \\
Without coQ10 & 33.75 & 28.40 & 263.45 \\
With coQ10 (30 & 29.70 & 25.40 & 246.75 \\
$\mu$ M) & 1.03 & 0.90 & 4.41 \\
ESM & $0.009^{* *}$ & $0.025^{*}$ & $0.012^{*}$ \\
P-value & \multicolumn{3}{l}{} \\
\hline
\end{tabular}

Interaction (ET x A):

P-value ns ns ns

Means in the same column for each factor with different superscripts differ significantly $(\mathrm{P}<0.05)$

NS: Not significant. *Significant at $\mathrm{P}<0.05$. ** Significant at $\mathrm{P}<0.01$.

\section{Fertility trail:}

Insemination of buffalo cows with thawed semen diluted with eMOLE+coQ10 resulted in the best fertility (conception rate of $91.66 \%$ ), followed by that diluted with eMOLE without coQ10 (conception rate of $83.33 \%$ ) and was the lowest for control extender, CEY (conception rate of $66.66 \%$ ) as shown in Table (6).

Table 6. Conception rate of buffalo cows artificially inseminated with frozen semen extended with CEY, and EMOLE with or without CoQ10.

\begin{tabular}{lccc}
\hline \multirow{2}{*}{ Item } & \multicolumn{3}{c}{ Conception rate } \\
\cline { 2 - 4 } & $\begin{array}{c}\text { Control } \\
\text { (CEY) }\end{array}$ & $\begin{array}{c}\text { eMOLE } \\
\text { without CoQ10 }\end{array}$ & $\begin{array}{c}\text { eMOLE with } \\
\text { CoQ10 }\end{array}$ \\
\hline $\begin{array}{l}\text { Inseminated } \\
\text { animals (n) }\end{array}$ & 12 & 12 & 12 \\
$\begin{array}{l}\text { Conceived animals } \\
\text { (n) }\end{array}$ & 8 & 10 & 11 \\
Rate of conception & 66.66 & 83.33 & 91.66 \\
\hline
\end{tabular}

\section{DISCUSSION}

The current study aimed to evaluate the freezability of buffalo semen with eMOLE without or with antibiotic (eMOLEa) as new types of extenders, or as a replacement for the antibiotic components of citrate egg-yolk (CEYm) as compared to a conventional type of extenders (CEY). These four types of extenders were also evaluated without or with adding coQ10 at levels of $30 \mu \mathrm{M}$. In this study motility, livability, abnormality, acrosome damage and plasma membrane integrity (HOS- $t$ ) were evaluated in semen after dilution, equilibration and thawing. It is well reported that sperm viability decreases more than $50 \%$ during cryopreservation process due to exposing spermatozoa to chemical / toxic, osmotic, thermal, and mechanical stresses during the stages of dilution, cooling, equilibration, or freezing and thawing process (Andrabi, 2009). The marked reduction in viability, livability, membrane integrity and acrosome occurred through freezing processes, and subsequently sperm morphological abnormalities increase (Meyers, 2005; Pena et al., 2009). During recent years, Moringa oleifera leave extract (MOLE) as aqueous, acetone and ethanolic extract possess antibacterial potential properties. Noteworthy that ethanolic 
extract of the plant demonstrated higher activity than aqueous extract, in term of antibiotics, ciprofloxacin, cotrimoxazole and chloramphenicol contents (Doughari et al., 2007). The recent results of El-Nagar (2017) on usage of MOLE as aqueous extract as an extender or as natural antioxidant for freezing Friesian bull semen encourage us to use MOLE as ethanolic extract or as a replacement of antibiotics in semen extender.

According to the obtained results, all sperm characteristic used in the current study were positively improved by using eMOLE or still to be as for control extender (CEY), when eMOLE was used as a replacement of antibitic. These findings could be attributed to that MOLE has antioxidant and antimicrobial properties as compared CEY or the industrial antibiotics used in this conventional extender. Such results are in agreement with Sokunbi et al. (2015), who successfully used MOLE as a replacement of antibiotic in bull semen extender as well as El-Nagar (2017), who used MOLE as an extender or as an antioxidant. Addition of antibiotics to semen extender was one of the first major advances to significantly improve the fertility potential of artificial insemination (AI) in bovine (de Jarnette et al., 2004). High percentage of normal sperm morphology is an indication of reduced microbial activities on the sperm cells (Sokunbi et al., 2015). Enhancement of fertility potential in bovine following AI is critically depending on adding of antibiotics to semen extender (de Jarnette et al., 2004). The present results are in agreement with current international standards of Certified Semen Services (CSS, 2011) regarding the antibiotic components of semen extenders and their recommendation for alternatives to streptomycin and penicillin (S\&P) in extender for buffalo bull semen preservation. For many years, S\&P considered the traditional antibiotic combination added to the diluents of buffalo bull semen. However, some of the microorganisms, which were previously sensitive to $\mathrm{S} \& \mathrm{P}$, may have become resistant to these antibiotics. (Andrabi et al., 2001; Hasan et al. 2001; Akhter et al., 2007).

Some authors put in evidence that none of these antibiotics was tested, in particular, S\&P, which were completely effective against bacterial growth in buffalo semen (Hasan et al., 2001; Akhter et al., 2008). An alternative combination of antibiotics is needed in semen extenders. According to Peixoto et al. (2011), ethanolic and aqueous MOLE contain several compounds with wide-spectrum anti-bacterial activity, which inhibit grampositive and negative bacteria growth. Based on the present results, replacement of traditional antibiotic (S\&P) with eMOLE proved to be efficient in eliminating bacterial growth and maintain semen characteristic after dilution, equilibration and thawing. Furthermore, MOLE is considered as a potent antioxidant due to its phenolic compounds, carotenoids, alkaloids, and proanthocyanidins, leading to acting as free radical terminators, reduces the destructive effects of oxidative stress, and decreases the need of antioxidant enzymes to counteract the increased free radicals (Pourmorad et al., 2006; Arabshahi et al., 2007).

Concerning the effect of coQ10 on animal reproduction, it was reported that the deficiency in CoQ10 may be the cause of asthenozoospermia in some male
(Lewin et al., 1997), and incubation of sperm cells with CoQ10 improved the pattern of bull sperm cells motility (Ibrahim et al., 2011; Thakur et al., 2013). This also proved in our study, whereas all extenders enhanced sperm parameters with coQ10 as compared to without addition, indicating antioxidant effect of coQ10 in buffalo semen extenders. This role was indicated in in vitro maturation medium of rabbit oocytes (Abdel-Khalek et al., 2016). Moreover, several authors reported that the fierce ROS effect on mobility and acrosomal damage of sperm cells could be diminished by CoQ10, especially in thawed semen (Saeed et al., 2016; Talevi et al., 2013).

The fertility rate is considered to be the best parameter to assess the quality of frozen-thawed semen (Vale, 1997). The final aim of buffalo bull sperm cryopreservation is the production of fertilized eggs after AI. A successful AI requires that a significant number of viable, fertile sperm cells are delivered at the site of fertilization in appropriate time (El-Sharawy et al., 2012). The recorded higher conception rate $(91.6 \%)$ achieved by cows inseminated by semen extended with eMOLE with coQ10 in the current study is satisfactory and mainly attributed to improving characteristics of spermatozoa in thawed semen, as well as lower activity of AST, ALT and LDH enzymes. Similarly, El-Nagar (2017) found the highest conception rate of Friesian cows artificially inseminated with semen extended with MOLE as compared to Tris egg-yolk. Such results were supported by the theory that, good quality of semen was characterized by lower AST, ALT and LDH of enzyme activity (Taha et al., 2000; Borah et al., 2015, El-Nagar, 2017). Generally, reducing activity of enzyme in seminal plasma of thawed semen is an indicator of membrane integrity, and subsequently sperm motility (El-Harairy et al., 2011)

\section{CONCLUSION}

Based on the foregoing results, eMOLE as a new extender, is promising for the extension and preservation of buffalo semen. Also, adding $4 \mathrm{ml}$ of eMOLE could be a good substitute for the antibiotic component of CEY as a conventional semen extender. Moreover, supplementing semen extenders with CoQ10 as an antioxidant at a level of $30 \mu \mathrm{M}$ is able to enhance sperm function and fertility of cryopreserved buffalo semen.

Further studies are required to evaluate different concentration of Moringa in extenders as antibiotics or antioxidants addition for improvement the thawed semen quality and fertility of buffalo bull semen. We need a new generation of semen extenders free from chemical, commercial antibiotics and based on Nature extracts according to guild lines of Certified Semen Services (CSS). Also, more studies are required to better understanding the properties of Moringa for enhancement of fertility characteristics of buffalo bull semen quality.

\section{REFERENCES}

Abdel-Khalek, A.E., I. T. El-Ratel, G.E. Younan, Sara, F. Fouda, W.M. Wafa and H. A. El-Nagar (2016). A potential role for coenzyme Q10 as energy and antioxidant agent in embryo production from follicular oocytes in rabbits. 11th World Rabbit Congress - January 15-18, Qingdao-China. 
Akhter S., M.S. Ansari, B.A. Rakha, S.M.H. Andrabi, S. Qadee, R. Iqbal and N. Ullah (2013). Efficiency of ciprofloxacin for bacterial control, post-thaw quality, and in vivo fertility of buffalo spermatozoa. Theriogenology, 80: 378-383.

Akhter S., M. Sajjad, S. M. H. Andrabi, N. Ullah, and M. Qayyum (2007). Effect of antibiotics in extender on fertility of liquid Buffalo bull semen. Pakistan Vet. J., 27(1):13-16.

Akhter S., MS Ansari, SMH Andrabi, N Ullah and M Qayyum (2008). Effect of antibiotics in extender on bacterial and spermatozoal quality of cooled buffalo (Bubalus bubalis) Bull Semen. Reprod Domest Anim, 43: 272 -278.

Andrabi, S. M. H., N. Ahmad, A. Abbas and M. Anzarb (2001). Effect of two different antibiotic combinations on fertility of frozen buffalo and Sahiwal bull semen. Pakistan Vet. J., 21: 166- 169.

Andrabi S. M. H., (2009). Factors Affecting the Quality of cryopreserved buffalo (Bubalus bubalis) bull spermatozoa. Reprod. Domest Anim, 44: 552-569.

Arabshahi DS, Devi V and A. Urooj (2007). Evaluation of antioxidant activity of some plant extracts and their heat, $\mathrm{pH}$ and storage stability. Food Chem., 100:1100-1105.

Borah, S.; Xi L.; Zaug, A.J.; Powell, N.M.; Dancik, G.M.; Cohen, S.B.; Costello, J.C.; Theodorescu, D. and T.R. Cech (2015). TERT promoter mutations and telomerase reactivation in urothelial cancer. Science, 347:1006-1010.

Campell R. C., H. M. Dott and T. D. Glover (1956). Nigrosin eosin as a stain for differentiating live and dead spermatozoa, Agr. Sc., 48, (1).

Certified Semen Services (CSS), 2002, CSS minimum requirements for health of bulls producing semen for AI, Missouri, USA.

Chatterjee S. and C. Gagnon (2001). Production of reactive oxygen species by spermatozoa undergoing cooling, freezing, and thawing. Mol. Reprod. \& Develop., 59: 451-458.

DeJarnette J. M., C. E. Marshall, R. W. Lenz, D. R. Monke, W. H. Ayars, and C. G. Sattler (2004). Sustaining the fertility of artificially inseminated dairy cattle: The role of the artificial insemination industry. J. Dairy Sci., 87: (E. Suppl.):E93-E104.

D'cruz and Mathur (2005). Effect of piperine on the epididymis of adult male rats. Asian J Androl, 7 (4): $363-368$.

Dougari, J. H., Pukuma, M. S. and N. De (2007). Antibacterial effects of Balanites aegyptiaca L. Drel. And Moringa oleifera Lam. on Salmonella typhi. Afri. J. of Biotech., Vol. 6 (19):2212-2215.

Duncan, D.B. (1955). Multiple Range and Multiple F. Test Biometrics, 11: 1-42.

El-Harairy, M.A.; Laila N. Eid; A.E.B. Zeidan; A.M. Abd El- Salaam, and M.A.M. El-Kishk (2011). Quality and fertility of the frozen-thawed bull semen as affected by the different cryoprotectants and glutathione levels. J. of Amer. Sci., 7(5):791-801.

El-Nagar, H.A. (2017). Effect of some semen extenders as a natural source of antioxidants on quality of frozen Friesian semen. J. Anim. Poul. Production, Mnsoura University, (9): 391-397.
El-Sharawy, M. E.; I. S.El-Shamaa; M.A.R. Ibrahim; I.M. Abd El-Razek; E.M. El-Seify (2012). Effect of low density lipoproteins in extender on freezability and fertility of Egyptian Buffalo bull semen. Anim. Sci. Series D, vol. LV.

Ewuola E. O. and G. N. Egbunike (2010). Effects of dietary fumonisin $\mathrm{B} 1$ on the onset of puberty, semen quality, fertility rates and testicular morphology in male rabbits. Reproduction, 139 439-445.

Hasan S, S.M.H. Andrabi, R. Muneer, M. Anzar , and N. Ahmad (2001). Effects of a new antibiotic combination on post-thaw motion characteristics and membrane integrity of buffalo and sahiwal bull spermatozoa and on the bacteriological quality of their semen. Pakistan Vet. J., 21, 6-12.

Ibrahim Siti Fatimah, Farah Hanan Fathihah Jaffar, Khairul Osman, Syarifah Faezah Syed Mohamed, Chew Fang Nang, Nur Hilwani Ismail, and Mohd Iswadi Ismail (2011). Bull spermatozoa motility: optimization of coenzyme Q10 and alpha-lipoic acid concentration. IIOABJ, 2 (5): 8-13.

Peixoto J. R. O., G. C. Silva, R. A. Costa, J. L. Fontenelle, G. H. F. Vieira, A. A. F. Filho, R. H. S. Vieira (2011). In vitro antibacterial effect of aqueous and ethanolic Moringa leaf extracts. Asi. Pacif. J. of Trop. Med., 201-204.

Jankovicovaj. M. Simon, and J. Antlikova (2006). Methods for evaluation of an acrosome reaction of bovine spermatozoa. Acta fytotechnica et zootechnica Mimoriadne číslo, 118.

Kadirve G., S. Kumar, S. K. Ghosh, P. Perumal (2014). Activity of antioxidative enzymes in fresh and frozen thawed buffalo (Bubalus bubalis) spermatozoa in relation to lipid peroxidation and semen quality. Asian Pacific Journal of Reproduction, 3(3): 210-217.

Kapoor P. and A.K. Kapoor (2013). Coenzyme Q10 - A novel molecule. JIACM, 14(1): 37-45.

Khan M. I. R. and A. Ijaz (2008). Effects of osmotic pressure on motility, plasma membrane integrity and viability in fresh and frozen-thawed buffalo spermatozoa. Animal, 2 (4): 548-553.

Lewin A., H. Lavon (1997). The effect of coenzyme Q10 on sperm motility and function. Mol Aspects Med., 18 Suppl: S213-9.

Lukacinova A., J. Mojzis, R. Benacka, J. Keller, T. Maguth, P. Kurila, L. Vasko, O. Racz and F. Nistiar (2008). Preventive Effects of Flavonoids on Alloxan-Induced Diabetes Mellitus in Rats. Acta Vet. Bron, 77: 175-182.

Meyers S.A., (2005). Spermatozoal response to osmotic stress. Anim. Reprod. Sci. 89, 57-64.

Mughal D H., A. Ijaz, M. S. Yousaf, H. Rehman, M. Aleem, H. Zaneb, I. Rabbani and F. Wadood (2013). The influence of taurine supplementation in lactose egg yolk glycerol extender for cryopreservation of Buffalo bull (Bubalus bubalis) semen. The J. of Anim. \& Plant Sci., 23(3), Page: 715-720.

Mughal D. H., A. Ijaz, M. S. Yousaf, F. Wadood and U. Farooq (2017). Cryopreservation of Buffalo (Bublus bubalis) semen -limitation and expectation. Buffalo Bulletin, (January-March) Vol.36 No.1 
Pakade V., E. Cukrowska, L. Chimuka (2013). Comparison of antioxidant activity of Moringa oleifera and selected vegetables in South Africa, S Afr J Sci., 109(3/4)

Pena, F.J.; R. Martinez, H.; J.A. Tapia ; C. O. Ferrusola; L. G. Fernandez and B. M. Garcia (2009). Mitochondria in mammalian sperm physiology and pathology. A review. Reprod. Domest. Anim., 44: 345-349.

Pindaru L. P., M. Cenariu, E. Pall, and I. S.Groza. (2013). Effects of coenzyme Q10 on sperm viability during storage of boar semen at 17o. Scientific Works. Series C. Veterinary Medicine; Vol. LXI (2).

Pourmorad F., S. J. Hosseinimehr, N. Shahabimajd (2006). Antioxidant activity, phenol and flavonoid contents of some selected Iranian medicinal plants. Afri. J. of Biotech. 5 (11): 1142-1145.

Sadek K. M., (2013). Chemotherapeutic efficacy of an ethanolic Moringa oleifera leaf extract against chromium-induced testicular toxicity in rats. Andrologia, 46, 1047-1054.

Arabshahi-D S., D. V. Devi, A. Urooj (2007). Evaluation of antioxidant activity of some plant extracts and their heat, $\mathrm{pH}$ and storage stability. Food Chem., 100: 1100-1105.

Saeed, A. M.; H. A. El-Nagar; W. M. Wafa and Y. S. Hussein (2016). Effect of coenzyme Q10 as an antioxidant added to semen extender during cryopreservation of buffalo and cattle semen. J. Anim. Poult. Prod. Mansoura Univ., 7 (11): 403 408.

Sansone G., M.J.F. Nastri and A. Fabbrocini, (2000). Storage of buffalo (Bubalus bubalis) semen. Anim. Reprod. Sci., 62: 55-76.

Siddhuraju P. and K. Becker (2003). Antioxidant properties of various solvent extracts of total phenolic constituents from three different agroclimatic origins of drumstick tree (Moringa oleifera Lam.) leaves. J. Agric. Food Chem., $51(8):$ 2144-2155.

Sokunbi O. A., O. S Ajani, A. A. Lawanson and E. A. Amao (2015). Antibiotic potential of Moringa leaf (Moringa oleifera Lam.) crude extract in bull semen extender. Europ.J. of Med. Plants, 9(2): 1-8, Article no.EJMP.18546.
SPSS Inc. Released 2013. IBM SPSS Statistics for Windows, Version 22.0. IBM Corp., Armonk, NY.

Taha, T.A.; E.I. Abdel-Gawad and M.A. Ayoub (2000). Monthly variations in some reproductive parameters of Barki and Awassi rams throughout 1 year under subtropical condition.2: Biochemical and enzymatic properties of seminal plasma. Anim. Sci., 71: 325.

Talevi R., V. Barbato, I. Fiorentino, S. Braun, S. Longobardi and R. Gualtieri. (2013). Protective effects of in vitro treatment with zinc, daspartate and coenzyme q10 on human sperm motility, lipid peroxidation and DNA fragmentation. Reprod. Biol. \& Endocrinol., 11:81.

Thakur A.S., G. P. Littaru, S. Moesgaard, C. Dan sindberg , Y. Khan, C. M. Singh (2013). Hematological parameters and RBC TBARS level of Q 10 supplemented tribal sickle cell patients: A hospital based study. Ind J Clin Biochem, 28(2):185-188.

Thibier M. and B. Guerin (2000). Hygienic aspects of storage and use of semen for artificial insemination. Anim Reprod Sci, 62, 233-251.

Tomono Y, J. Hasegawa, T. Seki, K. Motegi, N. Morishita (1986). Pharmacokinetic study of deuteriumlabelled coenzyme Q10 in man. Int $\mathrm{J}$ Clin Pharmacol Ther Toxicol, 24(10):536-41.

Ugwu Okechukwu P C, Nwodo Okwesili F C, Joshua Parker E, Bawa Abubakar, Ossai Emmanuel C and Odo Christian E (2013). Phytochemical and acute toxicity studies of Moringa oleifera ethanol leaf extract. Int. J. Life Sci. Biotechnol. Pharm. Res., 2, (2):66-71.

Pakade V., Cukrowska E., and Chimuka L., (2013). Comparison of antioxidant activity of Moringa oleifera and selected vegetables in South Africa, S Afr J Sci., 109(3-4): 01-05.

Vale WG, (1997). Sperm cryopreservation. Bubalus bubalis 1: 129-140.

Walczak R. J., J.K. Wolski, J.S. Hilczer (2012). The role of oxidative stress and antioxidants in male fertility. Central Europ. J. of Urol., 66 (1): 60-67.

Young, D.S. (1990). Effects of drugs on clinical laboratory tests. Third edition. 3:6-12.

\footnotetext{
تجميد وتقييم جودة السائل المنوي لطلائق الجاموس بإستخدام مخفف المورنجا الجديد ومضاد الأكسدة كوإنزيم كيو 10

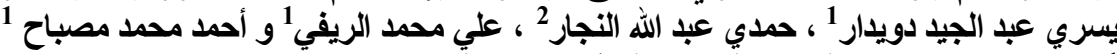

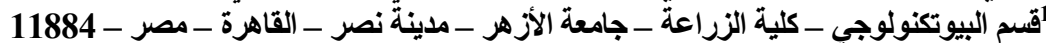

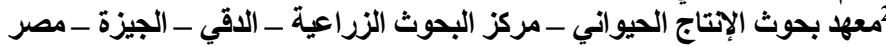

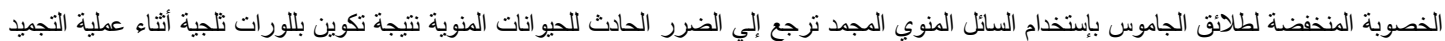

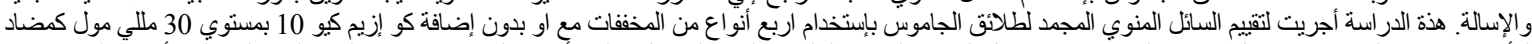

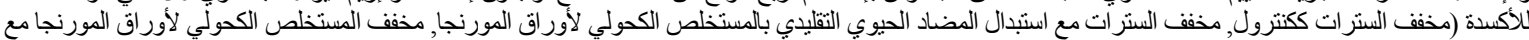

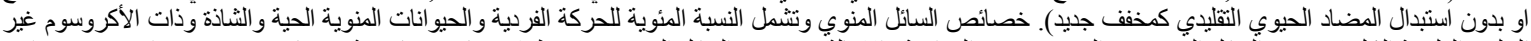

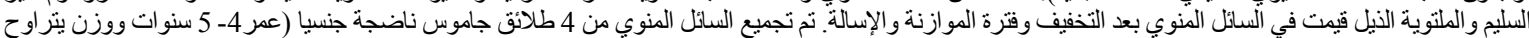

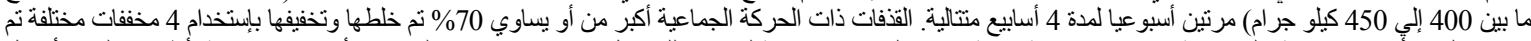

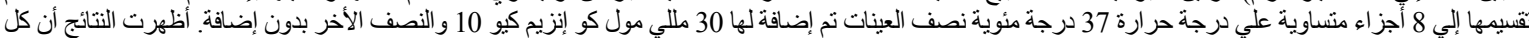

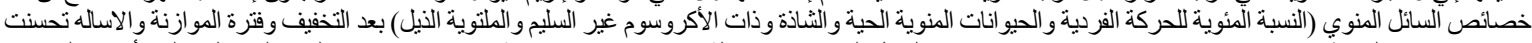

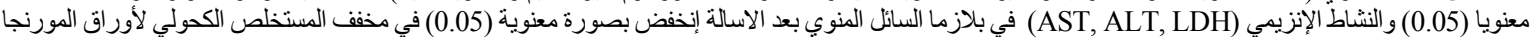

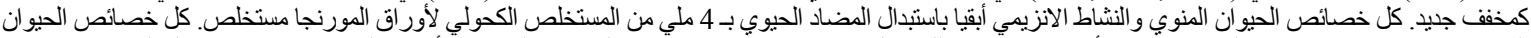

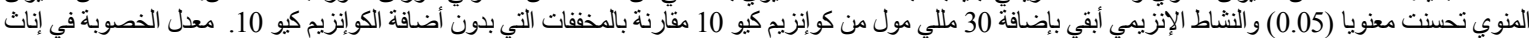

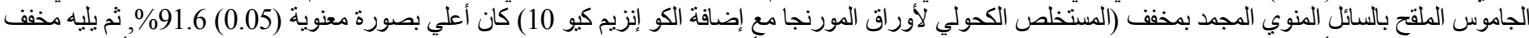

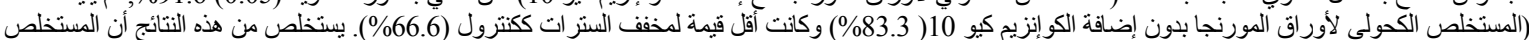

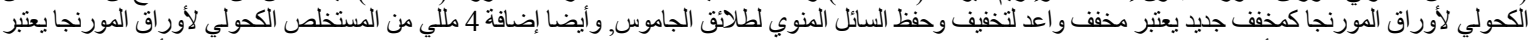

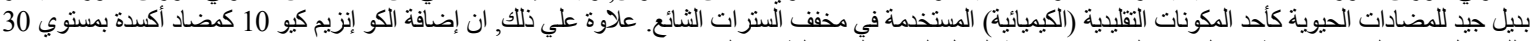
ملاي مول قادر علي تحسين وظائف الحيوان المنوي وخصوبة الكية السائل المنوي التهمد لطلائق الجاموس.
} 